\title{
Preparing students for service-learning and social entrepreneurship experiences
}

\author{
Chung, He Len ${ }^{\mathrm{a}}$; Taylor, Kayla ${ }^{\mathrm{a}}$ and Nehila, Caitlin ${ }^{\mathrm{a}}$
}

${ }^{\mathrm{a}}$ Psychology Department, The College of New Jersey, United States of America.

\begin{abstract}
A critical feature of contemporary models of civic engagement is mutuallybeneficial collaboration between campus and community partners, in which all members contribute skills and experience to co-create knowledge. At any given time, multiple relationships require attention - for example, triadic relationships between students, faculty, and staff of community organizations. This model is relevant for both service-learning (SL) and social entrepreneurship (SE), as both seek to work with community partners or in the community to address challenges facing the community. To date, research involving students has focused on the impact of these learning opportunities on student development (e.g., academics, civic participation). For students to be true partners in SL and SE projects, however, we need to understand the reciprocity of these interactions, particularly how to prepare students can become collaborators in developing campus-community partnerships (i.e., participatory readiness). To promote participatory readiness among students, we argue for a competency-based framework that integrates research and recommendations from the fields of service-learning, social entrepreneurship, and educational leadership. Throughout the article, we discuss similarities and differences in SL and SE practices and draw attention to the implications of the work for community engagement and pedagogy in higher education.
\end{abstract}

Keywords: service-learning; social entrepreneurship; community-engaged learning; competency framework; student leadership. 
During the last decade, a number of landmark statements have called for investing in higher education's public purpose to promote civic and social responsibility (e.g., Campus Compact, 2017). Specifically, two pedagogical approaches have gained increasing support as a way for higher education to pursue its public purpose: service-learning and social entrepreneurship. For this article, service-learning includes community engagement, civic engagement and other terms used on campuses; social entrepreneurship includes social innovation, social enterprise, and other terms used on campuses. With respect to servicelearning, Campus Compact has grown its membership since 1985 to nearly 1,100 colleges and universities that have made an institutional commitment to promoting responsible citizenship (2015). With respect to social entrepreneurship, Ashoka U has documented marked growth of curricular and co-curricular offerings in social entrepreneurship courses and related activities (Ashoka U, 2013).

Service-learning and social entrepreneurship, while distinct practices, share important similarities: both focus on experiential education, and both seek to work with community partners to address challenges facing the community. Programmatically, however, the two approaches often operate independently with limited exchange between them regarding learning goals, curricular content, and pedagogical strategies (Enos, 2015). Researchers in both fields have argued that their efforts can be improved by sharing knowledge, perspectives, and resources across boundaries (Enos, 2015; Jacoby, 2015; Janus, 2015; McBride \& Mlyn, 2015). Specifically, critics in both areas have suggested that we can better prepare our students to make meaningful contributions to community life if we build on the respective strengths of service-learning and social entrepreneurship practices. To address this recommendation, the current article considers "participatory readiness" (Allen, 2016) that targets students' role as important stakeholders in campus-community partnerships. Central to this notion is the belief that students need the knowledge, skills, and values to advance social change efforts in authentic ways. We draw specific attention to implications for the larger field of study of higher education, community engagement, and pedagogy.

\section{Challenges of Service-Learning and Social Entrepreneurship}

Although service-learning has been defined in various ways, there is general consensus that this form of experiential education engages students in activities that address human and community needs by integrating academic material, service activities that benefit the community, and critical reflection that allows students to connect academic material to broader issues (Jacoby, 1996). Course development focuses on helping students develop the knowledge, skills, values, and motivation to make a difference in the civic life of communities. Proponents of service-learning agree that the integrity of the work starts with 
reciprocity - that we relate to communities in the spirit of partnership. In their SOFAR model, Clayton and colleagues (Bringle \& Clayton, 2012) identified at least five important campus and community stakeholders: Students, staff of community Organizations, Faculty, Administrators on campus, and community Residents. In this model, each stakeholder brings a different perspective, and it is important that all partners contribute knowledge, skills, and experience to determine issues to address, questions to ask, problems to resolve, strategies to use, desired outcomes, and indicators of success (Bringle \& Clayton, 2012).

Although social entrepreneurship is defined in various ways, there is general consensus that the primary mission of this approach is to create social value by providing solutions to social problems (Dacin, Dacin, \& Tracey, 2011). While service-learning, as a pedagogical approach, developed inside higher education, social entrepreneurship developed outside of academia as an approach to solve problems in the "real world" (Enos, 2015). Despite initial resistance to it in higher education, social entrepreneurship found a home in graduate schools of business and, now, is steadily moving into other disciplines at both the undergraduate and graduate level, including engineering, law, public policy, psychology and social work. This shift makes pedagogical sense, as teaching social entrepreneurship requires striking a balance between both hard and soft skills, utilizing skills that can be found in both business and liberal arts schools (Dees, as quoted in Worsham, 2012). Education in these programs focus on teaching students the steps to organize resources around solving social problems, particularly business management skills and performance measures to develop sustainable solutions.

Service-learning and social entrepreneurship projects involving campus-community collaborations present significant educational opportunities, as well as challenges. One particular challenge is how to prepare students for these complex experiences that involve real-world stakeholders and real-world consequences. Developing collaborative relationships between campus and community partners is equally important for both types of projects (Clayton et al., 2010; Dees \& Anderson, 2006), but research suggests that authentic campus-community reciprocity is difficult to achieve in practice (Bortolin, 2011; Chung, Nordquist, Bates, \& Donohue, 2016; Cruz \& Giles, 2000; Stoecker, 2016). According to Stoecker (2016), a long-time service-learning educator, the current state of campus-community partnerships reflects how service-learning has become institutionalized in higher education. Specifically, service-learning practice on most campuses seems to emphasize (in order of importance) student learning, followed by service, community, and then change. He argues that if we truly want to achieve the goals of service-learning conducting meaningful work with community partners to address challenges facing the community - we need to change our priorities: change should be the most important, following by community, then service, and then learning. He recommends this shift in priorities not because student learning is less important, but because the primary goal of 
service-learning should shape the pedagogical activities. This recommendation is in line with the proponents of critical service-learning (see Daigre, 2000; Mitchell, 2008) who caution that any time we engage with constituency members we are ultimately influencing all relationships, sometimes with unintended negative outcomes for community stakeholders. For example, if a service-learning class tests a town's water and it turns up lead contamination, and the property values fall and the town's tax base declines, the project ultimately has worked against, rather than benefitted, community goals (Stoecker \& Tryon, 2009). To make change the priority in service-learning, we must emphasize authentic student preparation (Stoecker, 2016).

The field of social entrepreneurship has identified similar challenges. Researchers agree that students could benefit from a more critical analysis of root causes of social problems and an improved understanding of the process of social change within the field, including how to develop authentic campus-community reciprocity (Dacin et al., 2011; Janus, 2015). Similar to their service-learning colleagues, some social entrepreneur educators worry that viewing the work as "charity" can reify negative stereotypes of "others" and reinforce power imbalances in society, which can have unintended negative consequences (Morton, 1995; Dacin et al., 2011; Dees as quoted in Worsham, 2012). This is especially challenging for social entrepreneurship projects because students often have to balance social and commercial objectives (i.e., managing a double bottom line), which can create tensions across stakeholders (Pharoah, Scott, \& Fisher, 2004). Dacin et al. (2011) note a "dark side" to social entrepreneurship: that as the stakes increase and rewards are greater, exploitation and competition for resources come to the forefront. In some cases, broader and deeper awareness of social contexts within which change is proposed takes a back seat to notoriety and showcasing the change agent as a heroic individual.

\section{Toward a Unifying, Competency-Based Framework of Participatory Readiness}

Dostilio and Perry (2017) describe social entrepreneurship and service-learning (and other forms of community-campus engagement) as siblings, separated at birth, raised by two different sets of parents. Although they were "raised" in different contexts, both fields are interested in community and student impact and believe that interdisciplinary collaboration is essential if students are to be engaged with communities in productive and sustained ways (Schnaubelt and Rouse, 2013). In addition, both fields share a concern about addressing root causes that contribute to social problems and aim to develop students' capacity for public action. These similarities between service-learning and social entrepreneurship suggest that the two fields have complementary learning goals for its students, and integrating pedagogical strategies across fields has the potential to yield 
benefits for all stakeholders involved (Dees as quoted in Worsham, 2012; Dostilio \& Perry, 2017; Enos, 2015; Jacoby, 2015; McBride \& Mlyn, 2015).

In addition to integrating research from the fields of service-learning and social entrepreneurship, recent publications have linked the theory and practice of leadership and service-learning. Specifically, Wagner and Pigza (2016) argue that addressing 21 st century problems effectively requires 21 st century notions of leadership and social responsibility. With respect to service-learning and social entrepreneurship, the Social Change Model (SCM) of Leadership Development (HERI, 1996) provides a useful theoretical framework that can guide how we prepare students to engage with community partners and other stakeholders. The SCM of Leadership was created specifically for college students and defines leadership as a purposeful, values-based, collaborative process to achieve shared goals, rather than the characteristics or actions of one member (HERI, 1996). The model suggests that strong leadership skills are developed through collective action, shared power, and commitment to social change (Dugan \& Komives, 2007), all of which align with current calls in the fields of service-learning and social entrepreneurship education.

In general, competencies are understood as "integrated pieces of knowledge, skill, and attitude" that are common among a particular group of individuals working toward a goal (Lizzio \& Wilson, 2004). Knowledge involves knowing facts, knowing particular procedures, or having awareness of a process itself; skills are concerned with constructing, organizing, manipulating, sequencing, directing action toward goals; attitudes/values influence one's choice of actions, be they conscious or unconscious, implicit or explicit (Baartman \& de Bruijn, 2011). There is a valid concern that establishing a list of competencies promotes a singularly defined system of competence, which is defined in a particular cultural context and by those who are privileged to hold authority within a field of study or practice (Dostilio, 2017). This can be detrimental to those whose success is defined differently than the dominant worldview in which the competencies were developed or to those who are already marginalized within today's higher education environment (Jeris \& Johnson, 2004). Despite this concern, we believe that the word competency is a useful term for summarizing the knowledge, skill, and attitudes/values that we want to develop in our students.

Service-learning and social entrepreneurship education - somewhat independently - have already developed tools that can inform the development of a competency-based framework for participatory readiness. Most important, social entrepreneurship can benefit from service-learning's emphasis on campus-community reciprocity, while service-learning can benefit from social entrepreneurship's emphasis on impact assessment and sustainability (Dolgon, 2014; Jacoby, 2015). Specifically, the field of service-learning has presented models for identifying and understanding relationships between campus and community stakeholders (e.g., SOFAR model, Clayton et al. 2010), and the field of social 
entrepreneurship has presented models for understanding and assessing different levels of impact across all stakeholders, as well as social transformation (e.g., Ashoka's "Four Levels of Impact” framework, Kim 2015).

Finally, research in the field of leadership offers guidance about developing a model of student participatory readiness. Seemiller (2016) has described 60 student leadership competencies to consider for service-learning experiences and recommends narrowing the list to competencies most critical to the purpose of a specific activity or project. These competencies are organized into eight conceptual categories: learning and reasoning; selfawareness and development; group dynamics; interpersonal interaction; civic responsibility; communication; strategic planning; and personal behavior. Although these competencies were developed specifically with service-learning projects in mind, they provide a general framework for conceptualizing the knowledge, skills, and attitude/values that can prepare our students to conduct meaningful work with community partners that address shared goals.

\section{Conclusion}

Social interventions, whether promoted by service-learning, social entrepreneurship, or another type of initiative, most often fail because of a lack of attention to the context in which the work takes place, a failure to consider the concerns of stakeholders involves, and/or a failure to integrate feedback from individuals and groups who might be affected by the interventions (Enos, 2015). Co-collaboration between stakeholders is an essential key to a socially meaningful project, and if we want to help our students develop this type of "participatory readiness" (Allen, 2016), they must understand the dynamics of the community context in which they will be acting, as well as have the knowledge and skills to achieve their intended outcomes.

Both service-learning and social entrepreneurship education strive to prepare students to engage with communities in productive and sustained ways. Researchers in both fields have made significant advances toward helping students become stakeholders in campuscommunity partnerships; at the same time, many researchers agree that the work would benefit from building upon each field's respective strengths. Integrating knowledge across the two disciplines to develop a competency-based framework of participatory readiness has the potential to have meaningful impacts on all stakeholders involved. 


\section{References}

Allen, D. (2016). The future of democracy: The future of the humanities. Humanities, 37, 6-7.

Ashoka U. (2013). How do you know when you've revolutionized an industry? Ashoka's approach to assessing impact. https://www.changemakers.com/learning-lab/326891 (accessed March 26, 2017)

Baartman, L. K., \& de Bruijn, E. (2011). Integrating knowledge, skills and attitudes: Conceptualising learning processes towards vocational competence. Educational Research Review, 6(2), 125-134.

Bortolin, K. (2011). Serving ourselves: How the discourse on community engagement privileges the university over the community. Michigan Journal of Community Service Learning, 18(1), 49-58.

Bringle, R. G., \& Clayton, P. H. (2012). Conceptual framework for partnerships in service learning. In P. H. Clayton, R. G. Bringle \& J. A. Hatcher (Eds.), Research on service learning: Conceptual frameworks and assessment (pp. 539-572). Arlington, VA: Stylus.

Campus Compact. (2015). 2015 annual membership survey: Executive summary. Retrieved from http://kdp0143vw6z2dlw631ififc5.wpengine.netdna-cdn.com/wpcontent/uploads/2008/11/CC_AnnualSurvey_ExecutiveSummary_FINAL.pdf (accessed March 15, 2017).

Campus Compact. (2017). Thirtieth anniversary action statement of presidents and chancellors. Boston, MA: Campus Compact.

Chung, H. L., Nordquist, M., Bates, D. C., \& Donohue, P. (2016). Partnerships in civic engagement: Cultivating transformational campus-community relationships built to last. Social Behavior Research and Practice - Open Journal, 1(1), 22-33. doi:10.17140/SBRPOJ-1-105

Cruz, N., \& Giles, D. (2000). Where's the community in service-learning research? Michigan Journal of Community Service Learning, 7, 28-34.

Dacin, M. T., Dacin, P. A., \& Tracey, P. (2011). Social entrepreneurship: A critique and future directions. Organization Science, 22(5), 1203-1213.

Daigre, E. (2000). Toward a critical service-learning pedagogy: A Freirean approach to civic literacy. Academic Exchange, 4(4), 6-14.

Dees, J. G., \& Anderson, B. B. (2006). Framing a theory of social entrepreneurship: Building on two schools of practice and thought. In Mosher-Williams (Ed.), Research on social entrepreneurship: Understanding and contributing to an emerging field (pp. 39-66) Association for Research on Nonprofit Organizations and Voluntary Action.

Dolgon, C. (2014, April 11). Social enterprise and social justice in civic engagement. Email message to HE-SL Listserv.

Dostilio, L. D., \& Perry, L. G. (2017). An explanation of community engagement professionals as professionals and leaders. In L. D. Dostilio (Ed.), The community engagement professional in higher education: A competency model for an emerging field. Boston, MA: Campus Compact. 
Dugan, J. P., \& Komives, S. R. (2007). Developing leadership capacity in college students: Findings from a national study: A report from the Multi-Institutional Study of Leadership. College park, MD: National Clearinghouse for Leadership programs.

Enos, S. (2015). Service learning and social entrepreneurship in higher education: A pedagogy of social change. New York: Palgrave Pivot.

Higher Education Research Institute [HERI]. (1996). A social change model of leadership development: Guidebook version III. College Park, MD: National Clearinghouse for Leadership Programs.

Jacoby, B. (1996). Service-learning in today's higher education: An overview. In B. Jacoby (Ed.), Service-learning in higher education: Concepts and practices. San Francisco, CA: Jossey-Bass.

Jacoby, B. (2015). Service-learning essentials: Questions, answers, and lessons learned. San Francisco, CA: John Wiley \& Sons.

Janus, K. K. (2015). Bringing social entrepreneurship into the classroom. Stanford Social Innovation Review, June (1-3).

Jeris, L., \& Johnson, K. (2004). Speaking of competence: Toward a cross-translation for human resource development (HRD) and continuing professional education. Proceedings of Academy of Human Resource Development Annual Conference, 7(2) 1103-1110.

Kim, M. (2015). Rethinking the impact spectrum. Retrieved from https://ashoka.org/story/rethinking-impact-spectrum (accessed March 10, 2017).

Lizzio, A., \& Wilson, K. (2004). Action learning in higher education: An investigation of its potential to develop professional capability. Studies in Higher Education, 29(4), 469488.

McBride, A. M., \& Mlyn, E. (2015). Innovation alone won't fix social problems. The Chronicle of Higher Education, February (1-2).

Mitchell, T. D. (2008). Traditional vs. critical service-learning: Engaging the literature to differentiate two models. Michigan Journal of Community Service Learning, 14(2), 5065.

Morton, K. (1995). The irony of service: Charity, project and social change in servicelearning. Michigan Journal of Community Service Learning, 2(1), 19-32.

Pharoah, C., Scott, D., \& Fisher, A. (2004). Social enterprise in the balance. Glasgow: Charities Aid Foundation.

Pigza, J. M. (2016). Community partnerships: POWERful possibilities for students and communities. In W. Wagner, \& J. M. Pigza (Eds.), New directions for student leadership (pp. 49-59). New York: Wiley Periodicals.

Seemiller, C. (2016). Complementary learning objectives: The common competencies of leadership and service-learning. In W. Wagner, \& J. M. Pigza (Eds.), New directions for student leadership (pp. 23-35). New York: Wiley Periodicals.

Stoecker, R. (2016). Liberating service learning and the rest of higher education civic engagement. Philadelphia: Temple University Press.

Stoecker, R., \& Tryon, E. A. (Eds.). (2009). The unheard voices: Community organizations and service learning. Philadelphia: Temple University Press. 
Wagner, W. (2006). The social change model of leadership: A brief overview. Concepts \& Connections, 15(1), 9.

Wagner, W., \& Pigza, J. M. (2016). The intersectionality of leadership and servicelearning: A 21st-century perspective. In W. Wagner, \& J. M. Pigza (Eds.), New directions for student leadership (pp. 11-22). New York: Wiley Periodicals.

Worsham, E. L. (2012). Reflections and insights on teaching social entrepreneurship: An interview with Greg Dees. Academy of Management Learning and Education, 11(3), 442-452. 